\title{
An Exploratory Research of the Potential Strategic Benefits of Specialising in Riesling Grape: A Case Study from the Niagara Wine Region
}

\author{
Federico Topolansky Barbe ${ }^{1, *}$, Magdalena Gonzalez Triay ${ }^{2}$, Andrea Fujarczuc ${ }^{1}$ \\ ${ }^{1}$ School of Business and Entrepreneurship, Royal Agricultural University, UK \\ ${ }^{2}$ Marketing Department, University of Gloucestershire, UK
}

Copyright $\bigcirc 2016$ by authors, all rights reserved. Authors agree that this article remains permanently open access under the terms of the Creative Commons Attribution License 4.0 International License

\begin{abstract}
The main purpose of this paper is to evaluate the current business strategy of the Niagara wine region and to explore the potential of the Niagara wine region to specialise in Riesling grape variety. Questionnaires were administered to a range of different types of experts with a specialty in wine. Quantitative data from the Liquor Control Board of Ontario supplemented the core interviews. The results of this study indicate that differentiation through specialisation is the best strategy to develop the Niagara wine region. However, the structure of the wine industry encourages wineries to produce a vast array of grape varieties to cater to the needs of the domestic market. This has resulted in a loss of identity for the region. Though because Niagara Riesling is differentiable, world class, the most consistently awarded grape and unreproducible elsewhere, it is the prime candidate to become the representative grape for the region. By developing the Niagara style of Riesling and focusing on exporting small amounts of the variety, the region would benefit by developing an identity and increasing consumer confidence and sales.
\end{abstract}

Keywords Wine, Niagara, Business Strategy, Competitiveness

\section{Introduction}

The Niagara wine region is relatively young and has only been producing quality wine for several decades. It offers a wide range of grape varieties and wine styles. However, the region has never truly developed an identity in the world of wine. Therefore, the Niagara wine industry could benefit from gaining more direction. The lack of a clear strategy is preventing a further development of the Niagara wine region.

There is very limited research on business strategy to support the Niagara's wine region development. In particular, there is no research that has looked at the potential benefits of specialising in any grape varietal including Riesling. This research will partially address this gap in knowledge by gaining a deeper understanding of the potential benefits from adopting specialisation in Riesling. This study is relevant because it may help to determine whether the Niagara industry is producing wine with the greatest possible efficiency.

The specific objectives of this study are the following. First, to evaluate the potential of the Niagara wine region to specialise in Riesling grape. Second, to unveil if the Niagara wine region has a business strategy ensuring future successes.

\subsection{The Wine World}

The romance of wine has intrigued people for centuries and how aromas and tastes of such complicated chemical compounds have emerged from simple grapes continue to capture the public's attention Robinson [20].

Old World wine refers to wine regions in Europe but also some areas of the Mediterranean basin such as North Africa. The Old World uses traditional techniques and makes an effort to demonstrate the environment where wine is produced rather than using technology to create consistent wines Johnson \& Bruwer [11].

Old wine regions generally have guidelines as to what they are permitted to grow and be approved by their governing body. Many wineries are terroir (describes the "sense of place" from where it originates) driven and create single vineyard wine to best illustrate the area. These wines are often valuable, as they exemplify unique nuances provided by the distinctive terroir of the vineyard Robinson [20].

New World wine regions are regions located outside of Europe and started cultivating vines much later than the Old World. Though, this does not imply these regions only started making wine recently. The New World has less tradition and history in wine making, but there is much more 
diversity in styles. This has led to regions producing varietal expression, usually in the international recognizable varietals including Cabernet Sauvignon, Sauvignon Blanc and Pinot Noir.

\subsection{Ontario Wine Industry}

The Liquor Control Board of Ontario (LCBO) is an organisation established in 1927 to sell beer, wine and liquor LCBO [13]. It is run by the government and is held accountable by the Ministry of Finance. They are the only stores in Ontario which are permitted to sell alcohol liquor and wine with few exceptions. Restaurants and bars which are licensed are able to resell alcohol if it is sold on the premise. Additionally, wineries are able to acquire a licence which enables the winery to sell wines which are made on the location. The LCBO is the largest alcohol purchaser in the world, is taxed highly and contributes greatly to the Ontario government Ministry of Finance [15].

After prohibition grape growing was limited to growing vitis labrusca, a type of grape that is not suitable for making wines, but is preferred in jams or jellies Bramble and Gwyn [3]. It was thought the Ontario winters were too cold for the European wine grape, vitis vinifera, to survive. Therefore, Ontario focused on vitis labrusca and between 1930 and 1950 it developed many "Ports and Sherries". These wines were known for their "foxy flavours" and were not favoured among consumers Bramble \& Gwyn [3]. As a result of this, winemakers became fixated on developing French hybrids, less preferred grapes, and eventually developed European varieties such as Riesling, Chardonnay, Caberbets and Gamay Noir, though this was considered a great risk.

By the 1970s there was a lack of new commercial wineries because the government refrained from distributing more licences to manufacture wine. European immigrants with expertise in winemaking decided to challenge this and in 1974 Donald Ziraldo and Karl Kaiser petitioned the government to revoke the license law which prohibited new wineries from developing, and in 1975 they succeeded and eventually created the winery Inniskillin Bramble \& Gwyn [3].

Because technological advances were not available in the 1970s it took until 1990s for the industry to blossom. At this time, the industry was producing quality grapes but struggled to prove the quality and the premium winemaking techniques used to produce wine (Wine Country Ontario [24]). This resulted in the Ontario wine industry developing their response to France's AOC and Italy's DOCG in 1989: the Vintners Quality Alliance (VQA). The VQA was put into place to regulate the permitted amount of additions, winemaking practices and overall quality of the wines. This has helped to elevate Canadian consumers' idea of Canadian wines. This is also not to be confused with International Canadian Blends (ICB) which are Canadian grapes blended with grapes from other countries. ICB wines make up $73 \%$ of all Ontario wine sold and $54 \%$ of the total grapes grown Vintners Quality Alliance [23].
The Ontario wine industry has contributed significantly to the Ontario economy, contributing $\$ 6.8$ billion annually. Approximately 31,000 jobs in Canada are attributed to the wine industry and the industry welcomes more than 3 million visitors for tourism and revenue. It generates $\$ 1.2$ billion in employment and tourism revenue with $\$ 1.2$ billion going to liquor board mark up and federal and provincial tax revenue Canadian Vintners Association [4].

Sales in wine are growing constantly and in the last year alone sales grew $4.4 \%$. White wines gained $5.9 \%$ in the last year alone. From this, Riesling contributes $\$ 29.3$ million. More than $60 \%$ of the Riesling sold in Ontario is produced locally. The next largest producer of Riesling is Germany accounting for $29 \%$ of sales. Red wines are preferred and account for $59.3 \%$ of total sales Canadian Vintners Association [4]. Over $60 \%$ of these wines are sold over the $\$ 12.00$ price point with the highest amount of growth is in the $\$ 20-\$ 25$ price range. In addition, trends are showing wine drinkers are shifting back towards drinking more flavourful wine as well as sweeter wines, placing Riesling in an ideal position Cannavan [5].

Wine Country Ontario [24] has stated that in 2012 there was $\$ 40$ million of VQA wine exported with the United States being the most important market, followed by China, Singapore, South Korea and Japan. Exports represent only $10.4 \%$ of total sales. It is important to note that icewine alone contributes to $50 \%$ of this export.

\subsection{The Niagara Region}

The Niagara Peninsula is a diverse grape growing region in Canada making up 13,600 acres, and contributing to $65 \%$ of Ontario's wine production. Niagara is renowned for an abundance of fruit that grows in the region including cherries, peaches, strawberries and grapes Aspler [1]. There are four distinct physiographic areas: the Halimand Clay Plain, Lake Iroquois Plan, the Vinemount Morraine and the Niagara Escarpment Vintners Quality Alliance [23].

The Niagara Escarpment is an enormous rock formation that towers over Lake Ontario by approximately 335 metres. This creates an ideal environment in which grapes can grow and it functions as the coastline to the primordial sea Vintners Quality Alliance Ontario [23]. It provides elevation and slopes, dramatically affecting sunlight and breeze which contribute to the grapes ability to ripen. This escarpment is also responsible for creating thick layers of clay, additional silts and sands as well as shale bedrock which varies with drainage Aspler [1].

As one of the deepest great lakes, Lake Ontario functions as a moderator for the area. Winds which emerge from the lake protect the grape growing region from extreme cold temperatures. In the summer, warm winds emerge from Lake Ontario hit the wall of the Niagara Escarpment, reach the top of the escarpment, cool off, and circle downwards again Aspler [1]. This cools down grapes during heat waves and also dries out the grapes which protect them from frost. All these factors come together, to form a premier grape growing region Vintners Quality Alliance [23]. 


\subsection{Riesling}

Riesling is an outstanding variety of vitis vinifera, an internationally recognized European vine species from which most wine grapes are made Robinson [20]. Several authors have written about the exceptional characteristics of Riesling. The most notorious ones are: quality, ability to transform, delicacy, diversity, versatility, complexity and longevity Pigott [17]. It is renowned for its powerful aromas often offering mineral notes, lime, flowers and honey Fielden [7]. These characteristics will vary greatly depending on the region from which the grapes are coming, as it has an impressive ability to morph with unique soils and climate, similar to the red grape varietal Cabernet Sauvignon. It is an aromatic white wine which is also capable of creating elegant botrytis wines, sweet wines made from fungal infected grapes Johnson \& Bruwer [11].

Riesling is a type of grape variety that is known for its small to medium size berries which mature slowly and is particularly susceptible to powdery mildew and bunch rot. It is also considered a winter hearty grape with the ability to prune earlier than most other grape varieties. It is frost resistant, making it ideal for cooler climates. Riesling thrives in areas with limestone, shale and clay loam. In result of its natural high acidity, some Rieslings may undergo malolactic fermentation and very few undergo oak aging. Many are fermented cold to produce crisp racy Rieslings that are easy to drink Robinson [20].

Riesling prefers to grow in cool climate areas. It is best known for its delicate wines from the steep slopes of the Mosel Valley Veseth [22]. It was first documented in 1477 by the Duke of Lorraine in the region of the Alsace (France). In the late 19th century, it was a prized grape varietal, considered as reputable as the sophisticated red wines from France and by the late 1930s it made up 57 percent of the regions vineyards Robinson [20]. The grape extended into the Mosel, Saar-Ruwer, Nahe, Mittelrhein and Rheingau and some of these regions are dedicated exclusively to Riesling. Other countries which are noted to produce exceptional Rieslings include Australia, Austria, Germany, California, New Zealand and northern Italy Johnson \& Bruwer [11].

With the terroir provided by Niagara, Riesling is a prime grape candidate for the region with its cold hearty wood and high yields. When the first vitis vinifera were planted in Niagara in the 1970, Riesling was an obvious choice. In 1976, many of these vines were planted by Herman Weis, a German emigrant in search of a new home. By the 1980's Niagara became known for its Riesling and other Germans made the trek to Canada. Today, modern wineries in Niagara specialise in Riesling. Some of the most renowned wineries are: Thirty Bench, Flat Rock, Tawse, Hidden Bench, Featherstone, Twenty-Seven Cellars and Charles Baker Wine Country Ontario [24].

Despite 132 wineries being located in Ontario, only 96 wineries in the province produce Riesling with it amounting only to $17 \%$ (3.6 million litres) of Ontario's annual grape growing production. Most of the Riesling produced in
Ontario sells in the Ontario market, though some of it is exported to the U.S., Asia, and the UK, mainly in icewine form Grape Growers of Ontario [9].

There are many other grape varieties produced in Canada with Chardonnay being the most planted accounting for $18 \%$ of all VQA produced wine. Riesling is the second most produced grape (14\%) followed by Cabernet Franc (11\%) as well as Merlot (11\%), Vidal (8\%), Cabernet Sauvignon (7\%), Sauvignon Blanc (6\%), Pinot Noir (5\%), Pinot Gris (5\%) as well as other grape varieties Vintners Quality Alliance [23].

Icewine is a sweet dessert wine that gained the Niagara region international attention in 1991 when Kaiser and Ziraldo entered their Vidal icewine from Inniskillin produced in 1989 in Vin Expo in Bordeaux. It won one of the biggest wine awards in the world, the Prix D'Honneur Wine Country Ontario [24]. Most of Canada's icewine hail from Ontario, with the Niagara region producing the largest amount. This kind of wine can only be produced in a few regions in the world as it requires extreme heat to ripen the grapes and accumulate the sugars, followed by extreme cold to dehydrate the grapes Ziraldo \& Karl [25].

Germany has not always treated Riesling with the respect it deserves. During the great depression German winemakers looked to other markets to absorb their excess of wine. They turned to areas like Great Britain who were willing to purchase low cost wine and the German responded by producing low quality, sweet, shapeless wine, primarily from the Riesling grape and blended with other cheap varietals. There were always quality wines being produced from Germany, including Rieslings, but this depreciated the German wine brand and Riesling because its association with the country Veseth [22].

The International Riesling Foundation generated a voluntary sweetness scale which allows consumers to make better informed purchases. This can help to differentiate cheap sweet Rieslings from quality Rieslings and therefore give the consumers more confidence when purchasing wine. Currently, Riesling is now being called the "New Darling" as imports of the grape variety are constantly increasing Tinney [21].

\subsection{Specialisation and Differentiation}

In order to ensure maximum efficiency of efforts and resources, certain countries specialise in goods that are economically efficient to produce Carbaugh [6] \& Lee [14]. Research conducted by Huneeus [10] indicates that although there has been success in specialisation through marketing varietals, this can be duplicated by other regions. Though, what cannot be duplicated is the terror of the region in which the grape is being produced.

Many New World wine regions such as California, New Zealand and Australia have moved towards specialising in high quality wines which demonstrate regionality and express terroir. This strategy has allowed these regions to develop competitive advantage based on specialisation. Terroir makes competitive advantage developed within these 
regions difficult to imitate. This type of advantage is developed by demonstrating a characteristic which is unique and other firms find difficult to reproduce. By selecting attributes which consumers find desirable firms can charge a premium price Carbaugh [6].

As a region, Ontario would benefit from developing a differentiation advantage which would ideally result in a comparative advantage Lamb [12]. This would occur through the unique styles of Ontario wine, which would have the power to encourage the global market to increase its willingness to pay for wine from the region Grant [8].

Ontario currently has the opportunity to differentiate through its unique terroir and produce good quality wines demanded by consumers Mogk-Edwards [16]. According to Atkin and Johnson [2] the most important factors consumers look for as an indication of wine quality is the brand, and place of origin which includes region and country. One of the problems of the Ontario wine industry region is the production of many grape varietals, many of which are inefficient to produce Radebaugh et al., [18]. If the region were to develop a reputation for producing an excellent quality differentiated product, this could raise the overall perception of quality of the region and sub regions Johnson $\&$ Bruwer [11].

\section{Methodology}

An exploratory research design was used to achieve the envisaged aims of the study. This study follows in the established traditions in the field by taking a case study perspective at an industry/region level. Industry-level cases have sometimes been produced solely from secondary sources, but that is not the approach here.A combination of qualitative and quantitative methods was considered the most suitable approach for the purpose of this research. Interviews are an integral part of this study. The criterion used for selecting respondents was that they have expertise in the wine industry. Expert opinions were investigated using a similar set of questions depending on the type of expert being interviewed. A total of 16 face to face in-depth interviews were conducted with the following types of wine experts: winemakers (3), vineyards managers (2), winery owners (3), wine marketers (3), wine writers (2) and wine exporters (3). All participants were Canadian. The study participants were asked thirteen questions in a semi-structured interview format. The interviews were conducted in Ontario. Although all the experts have worked in the wine industry, not all of them have had first-hand experience of working in Niagara. This helped to give a better understanding of the regions wine industry from within and from outside of the Niagara. The data collection started in 2013, when the first exploratory interviews took place, and further interviews were conducted during 2014. All interviews lasted approximately two hours. Respondent's anonymity and privacy has been strictly preserved.

All interviews were digitally recorded and transcribed.
The transcribed interviews were rigorously coded and classified using the six step procedure Radnor [19]. The six key steps are: (1) topic ordering, (2) constructing categories, (3) reading for content, (4) completing coded sheets, (5) generating coded transcripts, and (6) analysis to interpretation. This technique allows the researcher to code whilst allowing the qualitative data to be linked, shaped and searched. Quantitative research helped to determine how many of the local and international awards are allocated to Riesling wines (still or icewine). Only the awards which have been awarded to the Niagara region were considered valid data and the awards from 2004-2013 were evaluated. The percentage of Riesling awards compared to other varieties was evaluated to determine whether there is a significance difference between the amount of awards given to the Niagara region and the amount of Riesling awards. Following this, the varieties winning gold medals were investigated and compared to the amount of awards Riesling has won. Quantitative data was collected from the LCBO. Interviews outcomes were confronted with quantitative data to make recommendations.

\section{Research Findings and Discussion}

\subsection{Qualitative Findings}

Respondents were asked about the best way to establish a wine region. Most interviewees claimed that a key route to success should be established. For them, there are three factors that must come together: personality (winemaker or owner), individuality (winery) and regionality. For this to happen, individual brand promotion and region promotion needs to be in synchrony. The findings also revealed that there are conflicting opinions on whether there is a plan for the future of the Ontario wine industry. For some interviewees (4), the plan focuses on selling locally. They believe this is a reflection of the multiculturalism of Canada and each sub culture wanting to do different things.

...The Niagara region does not have a great direction or focus apart from producing good quality wines. There are lots of politics which get in the way but there is not great plan for the future...(Respondent 14)

"...The concept of regionality only works if it has a reason for it to exist. In premium wine terms, how is it different? What is its point of difference? How does one wine region differ from another?..." (Respondent 2)

“...The Niagara region has lost its focus, but would benefit from a direction. VQA is evidence of the direction it used to have. The region may have a lot of passion but lacks business sense....(Respondent 4)

...The Ontario wine industry is very unique; a local winery can sell their wine to the $\angle C B O$ and it always has the possibility of buying more wine...(Respondent 11)

Findings suggest that although the Niagara region produces excellent quality Riesling, it has historically followed what the current local market desires. It should 
focus on varietals which it can produce at a better quality, which includes Riesling, and create more of a demand for better quality products locally (to an educated market), as can be costly for wineries to export. Niagara Riesling should also be better defined.

... There is a movement to go back to the varieties that are produced well, but there is also a movement to produce obscure wines for a niche market...(Respondent 15)

...The Niagara industry should produce what consumers want to purchase...(Respondent 2)

...It should keep exploring with new varieties and choose a number of varieties that it grows well to specialise in... (Respondent 16)

...Niagara Riesling is world class, unique and differentiated because of the soils and climate. Riesling grows well in Niagara and is very versatile...(Respondent 3)

Findings suggest that the Ontario industry is extremely regulated and limits the possibility to develop competitive advantage. Most interviewees suggested that the LCBO is an archaic organisation. For them, it is extremely difficult to develop a new stream of sales (because of remittances). The government monopoly creates limitations for selling wine within the province but it is also a large benefit to have the largest alcohol purchaser in the world located within the province. Because of this, small wineries have the opportunity to sell their wine to one purchaser and it will be sold in many different stores throughout the province. It has also become apparent that internal politics have not benefitted the region and most likely divided the original community which helped to form VQA.

...only recently has the $L C B O$ given local producer any kind of advantage, but they are starting to give Ontario producers an advantage in the $L C B O$... (Respondent 7) ... as a result of this monopoly, Ontario producers have been producing what consumers desire rather than what they can produce well and consistently. This has resulted in subpar wine being consumed...(Respondent 4)

Nearly all interviewees agreed that the story of the wine region has to reflect its wine values, not be contrived. The simpler this point of differentiation is, the easier it is for the consumer to understand it.

...Make sure your brand is unique, and something that other regions cannot replicate. The varietal cannot take over the marketing; it needs to reflect the style of the region...(Respondent 5)

The findings revealed that several respondents believe that specialising will help to increase exports from the region; permitting consumers understand what the speciality is. They also stated that specialisation does not have to be a varietal, it can be a style. The type of specialisation must consider the strategic position adopted by direct competitors.

...The key to establishing a region is by developing a story with a point of differentiation which is not replicated where winemaking and marketing are in unison with a consistent
quality...(Respondent 8)

...The Niagara region does not have a direction but it is starting to develop Niagara style Riesling which is a differentiable product and should concentrate on developing small success internationally, as there is a market for it, in order to develop local success...(Respondent 5)

...The region has to look at the long term and what makes sense for the climate...(Respondent 2)

...Specialising in a variety is important when establishing a wine region, but it can be a range of varieties or a single variety...(Respondent 13)

Half of the participants claimed that measurable success is a prerequisite for a region to develop. In their eyes, awards will attract agents which can open new international markets.

...Local consumers are aware of Niagara wine but there are conflicting opinions on whether there is an international market for Niagara Riesling...(Respondent 12)

...The Ontario wine industry faces many challenges from the government to export wine and is lacking direction...(Respondent 9)

Interviewees were further asked to express their thoughts about consumers' reactions to differentiation in grape varietal. Nearly all interviewees agreed that wine needs differentiation to stand apart. Consumers need a reason to choose a certain wine. However, they also pointed that wine lovers react to differentiation, but consumers may not.

...Riesling is extremely consumer friendly. It is simple to understand and appreciate, especially for average consumers... (Respondent 1)

...People are aware of Niagara, but only for icewine. Consumers might be more open to Riesling rather than icewine as it is more approachable... (Respondent 16)

...Most other New World wine regions produce many different varieties but only export their best and specialty wines....(Respondent 7)

...Generally Ontarians are not educated consumers. Consumers still associate Riesling with sweet and local consumers enjoy Niagara Riesling...(Respondent 6)

Nearly all interviewees agreed that most other New World wine regions produce many different varieties but only export their best and specialty wines. Findings suggest that Niagara Riesling needs to work on developing its unique identity. To gain a place in the very competitive consumers' mind space Niagara's identity needs to be perceived different from German Riesling.

...Concentrating on icewine internationally is great, Riesling also has great potential, but everything takes a long time. Most of the exports come from the larges wineries...(Respondent 14)

The majority of respondents stated that there are not many New World wine regions that produce Riesling, and many of them do not export. Many Old World wine regions also do not export. Therefore, there is a consensus regarding the potential for Riesling to grow. Respondents thought that 
there are not strategic gaps for other competitive varietals such as Chardonnay.

...Riesling needs to be pushed and only some wineries in Niagara are doing this... (Respondent 8)

...Consumers react to differentiation in wines and Niagara Riesling is world class and differentiable. It is a consumer friendly grape and is being sold in aromatic blends. Riesling grows well in Niagara climatically and economically and for winemaking reasons...(Respondent 5) ...Other New World wine regions have had great success with producing Riesling...(Respondent 3 )

Only a few interviewees stated that the future of the industry relies solely on local consumers. For them, the domestic market is much more attractive than exports. Therefore, they believe that wine firms should produce what Ontario consumers want. Two of them commented that local consumers are likely to choose local produce.

...New Zealand model exports because they need to, but Ontario doesn't need to export...(Respondent 11)

...The Niagara wine industry has some focus, pleasing consumers. The best opportunities are the local opportunities, at the LCBO...(Respondent 3)

... Ontario does not need to export because of the $L C B O$; New Zealand needs to export because of their small population...(Respondent 10)

...The Niagara region has the benefit of being located within the jurisdiction of the largest alcohol buyer in the world...it is more financially beneficial for wineries to sell wine to the LCBO than to export, resulting in low amounts of Ontario wine being exported and a diverse range of varieties being planted in Niagara..(Respondent 14)

Interviewees' attitude towards the export potential of the region is in general negative. The main reason is that Toronto consumers' are aware of Niagara wine but the international wine industry is not. Many respondents have the perception that international recognition has only been achieved by icewine and the region is trying to move away from that. However, two interviewees pointed that the Niagara wine region in spite of not being very well known internationally has a great opportunity to expand, with room to grow at the LCBO.

...The Niagara region cannot compete for low cost wine and it's not sustainable... (Respondent 12)

...International wine conferences have given the region more direction, this is bringing more awareness for the region but it will not happen rapidly...(Respondent 9).

...Niagara wines are not well known internationally outside of the elite tasters. Internationally there is a great demand for icewine, highly differentiated with high margins...(Respondent 9)

Table one below provides a summary of accumulated findings. NA implies they are not educated in the field, Y means yes, $\mathrm{N}$ means no $\mathrm{B}$ means they responded with both yes and no and I means interviewee.

Table 1. An accumulation of findings within the interviews conducted

\begin{tabular}{|c|c|c|c|c|c|c|c|c|c|c|c|c|c|c|c|c|}
\hline & $\mathrm{I}(1)$ & $\mathrm{I}(2)$ & I(3) & $\mathrm{I}(4)$ & $\mathrm{I}(5)$ & $\mathrm{I}(6)$ & $\mathrm{I}(7)$ & I $(8)$ & $\mathrm{I}(9)$ & $\mathrm{I}(10)$ & $\mathrm{I}(11)$ & $\mathrm{I}(12)$ & I(13) & $\mathrm{I}(14)$ & $\mathrm{I}(15)$ & $\mathrm{I}(16)$ \\
\hline $\begin{array}{c}\text { Is Niagara } \\
\text { Riesling } \\
\text { differentiable? }\end{array}$ & NA & Y & Y & Y & Y & Y & Y & $\mathrm{Y}$ & Y & Y & Y & Y & Y & Y & Y & $\mathrm{Y}$ \\
\hline $\begin{array}{l}\text { Is specialisation } \\
\text { the key to } \\
\text { developing a } \\
\text { region? }\end{array}$ & B & B & B & Y & B & Y & B & B & B & B & Y & Y & B & B & B & B \\
\hline $\begin{array}{c}\text { Is Niagara } \\
\text { Riesling fully } \\
\text { developed? }\end{array}$ & NA & $\mathrm{N}$ & $\mathrm{N}$ & $\mathrm{N}$ & B & $\mathrm{N}$ & $\mathrm{N}$ & $\mathrm{N}$ & $\mathrm{N}$ & $\mathrm{N}$ & B & $\mathrm{N}$ & $\mathrm{N}$ & $\mathrm{N}$ & $\mathrm{N}$ & B \\
\hline $\begin{array}{c}\text { Does the } \\
\text { Niagara region } \\
\text { have direction? }\end{array}$ & NA & $\mathrm{N}$ & $\mathrm{N}$ & B & B & B & B & $\mathrm{N}$ & $\mathrm{N}$ & $\mathrm{N}$ & $\mathrm{N}$ & $\mathrm{N}$ & $\mathrm{N}$ & B & $\mathrm{N}$ & $\mathrm{N}$ \\
\hline $\begin{array}{c}\text { Should the } \\
\text { Niagara region } \\
\text { look to export? }\end{array}$ & NA & Y & B & B & B & B & B & B & Y & Y & Y & $\mathrm{N}$ & B & B & B & $\mathrm{Y}$ \\
\hline $\begin{array}{l}\text { Is there room for } \\
\text { Niagara region } \\
\text { to grow in the } \\
\text { LCBO }\end{array}$ & NA & Y & Y & Y & Y & Y & Y & $\mathrm{N}$ & Y & Y & Y & Y & Y & $\mathrm{N}$ & Y & $\mathrm{Y}$ \\
\hline $\begin{array}{c}\text { Does Riesling } \\
\text { grow well in } \\
\text { Niagara? }\end{array}$ & NA & Y & Y & Y & Y & Y & Y & Y & Y & Y & Y & Y & Y & Y & $\mathrm{Y}$ & $\mathrm{Y}$ \\
\hline $\begin{array}{c}\text { Is there room for } \\
\text { a New World } \\
\text { Riesling? }\end{array}$ & Y & Y & NA & NA & NA & NA & $\mathrm{Y}$ & Y & Y & NA & NA & Y & Y & Y & Y & NA \\
\hline $\begin{array}{c}\text { Do you think } \\
\text { Riesling is a } \\
\text { consumer } \\
\text { friendly grape? }\end{array}$ & Y & Y & Y & Y & Y & Y & $\mathrm{Y}$ & Y & Y & $\mathrm{Y}$ & Y & Y & Y & Y & $\mathrm{Y}$ & $\mathrm{Y}$ \\
\hline
\end{tabular}

Source: Results of the study, 2014.

Note. NA implies that interviewees are not educated in the field, Y means yes, N means no and B means interviewees responded with both Yes and No. 
The analysis of data allowed unveiling important factors shaping the structure of the Niagara wine region as well as potential opportunities for development. All targeted experts agreed that Riesling is a consumer friendly grape and is differentiable when produced in the Niagara style. This study has also revealed that Riesling is a grape that grows well in the Niagara region and creates world class wines but the style has not been fully developed, though there are wineries who have tried to develop it further. There is a lot of work to do in order to increase the international reputation of this wine. The study has also revealed that because of the government restraints and production limits Niagara will never be able to become a leading exporter of wine. However, they all agree there is room for growth for local product in the LCBO and wineries should push for more wines sold locally.

\subsection{Quantitative Findings}

This section will look at the results of the Decanter Wine Awards and the results of the Lieutenant Governors Wine Awards.
Findings indicate the percentage of still Riesling gold medals is $67 \%$. This is an impressive figure indicating there were only other two wines which have been entered into this competition and achieved the same recognition for a still wine from Niagara. This demonstrates that Riesling is the grape variety which has the most potential to most consistently win top awards for its still wines.

The percentage of gold medals of icewine which are made from Riesling is approximately $29 \%$. This is most likely because there are other grape varieties which produce outstanding icewine such as Cabernet Franc and Vidal. Although winning $38 \%$ less than the still awards, it still received almost a third of all the gold icewines awards, demonstrating Riesling is capable of excellence when made into icewine.

The total average of percentage of all Niagara gold medals which are made from Riesling is $47 \%$. The percentage of regional awards which were awarded for Riesling is $50 \%$, demonstrating that it has been recognised by the Decanter Wine Awards as an outstanding varietal from the region.

Table 2. Percentage of Decanter Wine Awards awarded to the Niagara Region for Riesling

\begin{tabular}{|c|c|c|c|c|c|c|c|c|c|c|c|}
\hline Decanter Wine Awards (Year) & 2013 & 2012 & 2011 & 2010 & 2009 & 2008 & 2007 & 2006 & 2005 & 2004 & 2003 \\
\hline Total still gold medals & 2 & 3 & 0 & 1 & 0 & 0 & 0 & 0 & 0 & 0 & 6 \\
\hline Total still Riesling gold medals & 2 & 1 & 0 & 1 & 0 & 0 & 0 & 0 & 0 & 0 & 4 \\
\hline $\begin{array}{l}\text { Percentage still Riesling gold } \\
\text { medal }\end{array}$ & $100 \%$ & $33 \%$ & $0 \%$ & $100 \%$ & $0 \%$ & $0 \%$ & $0 \%$ & $0 \%$ & $0 \%$ & $0 \%$ & $67 \%$ \\
\hline Total icewine gold medals & 2 & 1 & 0 & 0 & 1 & 2 & 0 & 0 & 0 & 1 & 7 \\
\hline $\begin{array}{l}\text { Total Riesling icewine gold } \\
\text { medals }\end{array}$ & 1 & 0 & 0 & 0 & 0 & 1 & 0 & 0 & 0 & 0 & 2 \\
\hline $\begin{array}{l}\text { Percentage Riesling gold } \\
\text { medal icewine }\end{array}$ & $50 \%$ & $0 \%$ & $0 \%$ & $0 \%$ & $0 \%$ & $50 \%$ & $0 \%$ & $0 \%$ & $0 \%$ & $0 \%$ & $29 \%$ \\
\hline Total Riesling gold medals & 3 & 1 & 0 & 1 & 0 & 1 & 0 & 0 & 0 & 0 & 6 \\
\hline Total gold medals & 4 & 4 & 0 & 1 & 1 & 2 & 0 & 0 & 0 & 1 & 13 \\
\hline $\begin{array}{l}\text { Percentage of gold medals } \\
\text { from Riesling }\end{array}$ & $75 \%$ & $25 \%$ & $0 \%$ & $100 \%$ & $0 \%$ & $50 \%$ & $0 \%$ & $0 \%$ & $0 \%$ & $0 \%$ & $46 \%$ \\
\hline Total regional awards & 1 & 1 & 2 & 3 & 1 & 0 & 1 & 0 & 0 & 1 & 10 \\
\hline Riesling regional awards & 1 & 1 & 0 & 1 & 0 & 0 & 1 & 0 & 0 & 1 & 5 \\
\hline $\begin{array}{c}\text { Percentage Riesling regional } \\
\text { awards }\end{array}$ & $100 \%$ & $100 \%$ & $0 \%$ & $33 \%$ & $0 \%$ & $0 \%$ & $100 \%$ & $0 \%$ & $0 \%$ & $100 \%$ & $50 \%$ \\
\hline $\begin{array}{c}\text { Total gold medals and regional } \\
\text { awards }\end{array}$ & 5 & 5 & 2 & 4 & 2 & 2 & 1 & 0 & 0 & 2 & 23 \\
\hline $\begin{array}{l}\text { Total Riesling gold medals and } \\
\text { regional awards }\end{array}$ & 4 & 2 & 0 & 2 & 0 & 1 & 1 & 0 & 0 & 1 & 11 \\
\hline $\begin{array}{c}\text { Percentage of Riesling from } \\
\text { gold medals and regional } \\
\text { awards }\end{array}$ & $80 \%$ & $40 \%$ & $0 \%$ & $50 \%$ & $0 \%$ & $50 \%$ & $100 \%$ & $0 \%$ & $0 \%$ & $50 \%$ & $48 \%$ \\
\hline Silver medals & 8 & 7 & 5 & 11 & 12 & 12 & 3 & 4 & 1 & 4 & 67 \\
\hline Riesling silver medals & 1 & 1 & 1 & 1 & 2 & 3 & 0 & 2 & 0 & 2 & 13 \\
\hline $\begin{array}{c}\text { Percentage of Riesling silver } \\
\text { medals }\end{array}$ & $13 \%$ & $14 \%$ & $20 \%$ & $9 \%$ & $17 \%$ & $25 \%$ & $0 \%$ & $50 \%$ & $0 \%$ & $50 \%$ & $19 \%$ \\
\hline Bronze medals & 28 & 20 & 29 & 17 & 16 & 23 & 9 & 8 & 7 & 3 & 160 \\
\hline Riesling bronze medals & 3 & 3 & 2 & 3 & 2 & 2 & 1 & 1 & 2 & 1 & 20 \\
\hline $\begin{array}{l}\text { Percentage of Riesling bronze } \\
\text { medals }\end{array}$ & $11 \%$ & $15 \%$ & $7 \%$ & $18 \%$ & $13 \%$ & $9 \%$ & $11 \%$ & $13 \%$ & $29 \%$ & $33 \%$ & $13 \%$ \\
\hline
\end{tabular}

Source: Decanter Worldwide Awards, 2014 
Table 3. Gold Decanter awards arranged by variety

\begin{tabular}{|c|c|c|c|c|c|c|c|c|c|c|c|c|c|}
\hline & 2004 & 2005 & 2006 & 2007 & 2008 & 2009 & 2010 & 2011 & 2012 & 2013 & Average & Total & $\%$ \\
\hline Riesling & 0 & 0 & 0 & 0 & 1 & 0 & 1 & 0 & 1 & 3 & 0.6 & 6 & 46 \\
\hline Gewürztraminer & 1 & 0 & 0 & 0 & 0 & 0 & 0 & 0 & 1 & 0 & 0.2 & 2 & 15 \\
\hline Vidal & 0 & 0 & 0 & 0 & 1 & 0 & 0 & 0 & 1 & 1 & 0.3 & 3 & 23 \\
\hline Cabernet Franc & 0 & 0 & 0 & 0 & 0 & 1 & 0 & 0 & 0 & 0 & 0.1 & 1 & 8 \\
\hline Merlot & 0 & 0 & 0 & 0 & 0 & 0 & 0 & 0 & 1 & 0 & 0.1 & 1 & 8 \\
\hline Total & 1 & 0 & 0 & 0 & 2 & 1 & 1 & 0 & 4 & 4 & 1.3 & 13 & 100 \\
\hline
\end{tabular}

Source: Decanter Worldwide Awards, 2014.

The above quantitative data indicates that Riesling has won $46 \%$ of the gold awards given to the Niagara region with a total of six, the highest average per year. This is because it has won four out of the total six awards given to Niagara for still wines as well as almost a third of all of the icewine awards.

Vidal was the second most awarded grape variety having won $23 \%$ of all gold awards, totalling three awards, with the second highest average per year. It is world renowned for its icewine capabilities and all of the awards given to Vidal have been for its Riesling. Gewurztraminer was the third most awarded grape variety from the Niagara region having won a total of two awards, amounting to $15 \%$ of the awards and had the third highest average. This won an award for its still wine as well as its icewine. Both Merlot and Cabernet Franc each make up $8 \%$ of the total gold awards given to the Niagara region, having won one award each and had the lowest average of all the award receiving varietals. The Merlot won for a still wine while the Cabernet Franc won the award for an icewine.

It is important to note that although Chardonnay was discussed in many of the interviews as one of Niagara's most suitable grape varieties; it has not won a gold award at the Decanter Wine Awards.

Table 4. Percentage of Lieutenant Governors Wine Awards awarded to Riesling Niagara Region for Riesling

\begin{tabular}{|c|c|c|c|c|}
\hline $\begin{array}{c}\text { Ontario Lieutenant Governor } \\
\text { Awards }\end{array}$ & 2013 & 2012 & 2011 & $\begin{array}{c}\text { Total } \\
\text { (Average) }\end{array}$ \\
\hline $\begin{array}{c}\text { Total number of still and } \\
\text { sparkling wines }\end{array}$ & 10 & 9 & 10 & 29 \\
\hline $\begin{array}{c}\text { Total number of still Niagara } \\
\text { Rieslings }\end{array}$ & 2 & 2 & 3 & 7 \\
\hline $\begin{array}{c}\text { Percentage of awards won by } \\
\text { still Riesling }\end{array}$ & $20 \%$ & $22 \%$ & $30 \%$ & $24 \%$ \\
\hline Total number of icewine & 2 & 2 & 2 & 6 \\
\hline $\begin{array}{c}\text { Total number of Niagara } \\
\text { Riesling icewine }\end{array}$ & 1 & 1 & 1 & 3 \\
\hline $\begin{array}{c}\text { Percentage of awards won by } \\
\text { Riesling icewines }\end{array}$ & $50 \%$ & $50 \%$ & $50 \%$ & $50 \%$ \\
\hline Total number of Rieslings & 3 & 3 & 4 & 10 \\
\hline Total number of awards & 12 & 11 & 12 & 35 \\
\hline $\begin{array}{c}\text { Percentage of awards won by } \\
\text { Riesling }\end{array}$ & $25 \%$ & $0.27 \%$ & $33 \%$ & $29 \%$ \\
\hline
\end{tabular}

Source: Lieutenant Governor Awards, 2014.

The above data indicates that Riesling has averaged approximately $24 \%$ of the total still and sparkling awards, ranging from $20-30 \%$ over the course of three years. It has always been awarded between 2-3 awards for still Riesling every year. This identifies that local expert recognise that Niagara Riesling stands out among all the other different varieties, and consistently represents excellence in Ontario wines. It has won on average $50 \%$ of the total icewine, winning half of the icewine awards every year of the competition. This implies that local experts can identify that Riesling makes excellent icewine.

Table 5. Lieutenant Governor Wine Awards arranged by variety

\begin{tabular}{|c|c|c|c|c|c|c|}
\hline & 2011 & 2012 & 2013 & Average & $\begin{array}{c}\text { Total } \\
\text { awards }\end{array}$ & Percentage \\
\hline Riesling & 4 & 3 & 3 & 3.3 & 10 & $28.6 \%$ \\
\hline Chardonnay & 2 & 2 & 3 & 2.3 & 7 & $20.0 \%$ \\
\hline Gamay & 1 & 1 & 0 & 0.7 & 2 & $5.7 \%$ \\
\hline Pinot Noir & 1 & 0 & 0 & 0.3 & 1 & $2.9 \%$ \\
\hline $\begin{array}{l}\text { Rose } \\
\text { Blends }\end{array}$ & 1 & 0 & 0 & 0.3 & 1 & $2.9 \%$ \\
\hline Vidal & 1 & 1 & 1 & 1.0 & 3 & $8.6 \%$ \\
\hline $\begin{array}{l}\text { Meritage } \\
\text { Blends }\end{array}$ & 1 & 1 & 1 & 1.0 & 3 & $8.6 \%$ \\
\hline $\begin{array}{c}\text { Cabernet } \\
\text { Franc }\end{array}$ & 0 & 2 & 1 & 1.0 & 3 & $8.6 \%$ \\
\hline $\begin{array}{c}\text { Champagne } \\
\text { Blend }\end{array}$ & 1 & 1 & 0 & 0.7 & 2 & $5.7 \%$ \\
\hline Merlot & 0 & 0 & 1 & 0.3 & 1 & $2.9 \%$ \\
\hline $\begin{array}{c}\text { Cabernet } \\
\text { Sauvignon } \\
\end{array}$ & 0 & 0 & 1 & 0.3 & 1 & $2.9 \%$ \\
\hline Syrah & 0 & 0 & 1 & 0.3 & 1 & $2.9 \%$ \\
\hline Total & 12 & 11 & 12 & 11.7 & 35 & $100 \%$ \\
\hline
\end{tabular}

Source: Lieutenant Governor Awards, 2014.

Table five indicates that Riesling has won $29 \%$ of the total awards over the course of three years, ranging from three to four awards every year. It has totalled ten awards over the course of three years for both still wine and icewine.

The two competitions were compared to determine whether there were consistencies in award winning grape varieties. It is important to note that there were a total of 35 Lieutenant Governor Wine awards awarded while there were only 13 gold Decanter Wine Awards given to the Niagara region. This will skew percentages, but will still highlight consistencies and inconsistencies between varieties. 
Riesling was very popular having won consistently the highest amount of awards in both the Decanter Wine Awards as well as the Lieutenant Wine Awards. Although Chardonnay accumulated $20 \%$ of the total Lieutenant Governor Wine Awards, Niagara Chardonnay has not won any gold medals from the Decanter Wine Awards.

In the Lieutenant Governor Wine Awards, Vidal was very popular having won $9 \%$, which is fairly consistent, having won $15 \%$ of the gold medal Decanter Wine Awards. All of the awards were given for icewine.

Although Gewurztraminer was awarded $8 \%$ of the gold Decanter Wine Awards, it has not won a single Lieutenant Governor Wine Award showing inconsistency. Merlot also showed inconsistency having won $8 \%$ if the Decanter Wine awards but has only won less than $1 \%$ of the awards at the Lieutenant Wine Awards. Cabernet Franc won $8 \%$ of the Decanter Wine Awards and was awarded 9\% of the Lieutenant Governor Wine Awards.

As Riesling was the most awarded wine in the two competitions investigated, is considered a grape which grows well in the area and has the ability to develop a distinct style which is not reproducible, it could be used as a model to develop regions identity and help raise the quality and consumer confidence in Ontario wines. Though, because of the demands of the LCBO consumers, the Ontario wine industry should continue to produce a selection of grape varieties.

\section{Recommendations}

\subsection{Encourage Wineries to Develop Niagara Style Riesling}

Through quantitative research, it has been determined that Niagara Riesling is a consistent winner at both international and local awards. The grape variety has proven to thrive consistently in the area and produce high quality wine. This is supported by qualitative findings.

The region used much of the information acquired in Germany to learn how to grow Riesling in Niagara. This has helped the Niagara industry to develop quickly and produce high quality wines. Though Niagara will continue to learn how to grow grapes, including Riesling from other regions around the world, the region should focus on better defining the Niagara style of Riesling. This can be explored through viticulture and vinification including using different clones, discovering what the local terroir has to offer and should focus on what makes Riesling from this region different than from any other region worldwide.

By continuing to explore what Riesling has to offer when grown in Niagara, the identity of the style will become more defined, creating a quality, differentiable product which cannot be replicated by any other region. This will help to give the region an identity with a simple message which consumers can understand.

\subsection{Focus on Exporting Riesling}

Only a small percentage of Ontario wine is exported and approximately half of it is icewine. Because there is not a significant amount of still wine being exported from the country there is little awareness of still wine from Ontario.

In order to develop international recognition, winemakers, winery owners and marketers need to work in unison to develop individuality, personality and regionality. By exporting too many grape varieties in a range of styles, consumers are having problems understanding what the region has to offer. Many wine regions around the world produce a vast array of varieties but they only export the wines which offer the styles for which they are best known. This gives the consumer a message which they can understand which helps developing international recognition for the region.

Although Niagara will never be a leading exporter, it still can gain international recognition by exporting small amounts of world class Riesling which will enable consumers to understand a simple message: Niagara Riesling is world class, cool, crisp and Canadian.

\subsection{Emphasize the Quality of Riesling at the LCBO}

There is a great opportunity for the LCBP to promote the quality of Ontario wines. At the moment, local wines are not perceived by Ontarians' consumers to be very high quality. Probably this perception is influenced by low quality wines that were produced 30 years ago. If the LCBO and Ontario wineries started to promote Riesling as a local and world class product, Ontarians may be more inclined to consume Ontario wines.

By facilitating more locals to try a high quality product which can be produced consistently and locally, this may increase consumer confidence levels when purchasing wine from Niagara. Using Niagara Riesling as the entry wine for many locals who have not tried Ontario wines or have had bad experiences with Ontario wines may facilitate higher sales at the LCBO for local wines, creating a larger market share as well as higher sales for Ontario wineries.

\section{REFERENCES}

[1] Aspler, T (2013). Canadian Wineries. Toronto: Random House Canada. Print.

[2] Atkin, T. \& Johnson, R. (2010). Appellation as an indicator of quality. International Journal of Wine Business Research, 22(1), 42-61.

[3] Bramble, L. \& Gwyn, C. (2007). Wine, Society, and Globalization: Multidisciplinary Perspectives on the Wine Industry. New York, NY: Palgrave Macmillan. Print.

[4] Canadian Vintners Association, (2014). Canadian Wine and Grape Industry Contributes $\$ 6.8$ Billion. Retrieved from: 
http://www.businesswire.com/news/home/20130305005687/ en/Canadian-Wine-Grape-Industry-Contributes-6.8-Billion

[5] Cannavan, T. (2013). About New Zealand wine. Retrieved from http://www.wine-pages.com/resources/nzexp.htm

[6] Carbaugh, R. (2009). Cram101 Textbook Reviews. Study Guide for International Economics, ISBN 9780324581485. Edition. AIPI.

[7] Fielden, C. (2004). Exploring the World of Wines \& Spirits. Wine \& Spirit Education Trust.

[8] Grant, R.M. (2010). Contemporary Strategy Analysis and Cases: Text and Cases. 7th Edition. Willey.

[9] Grape Growers of Ontario. (2012). Ontario Grape Growers expect demand for 2012 Ontario wine to soar following record harvest and global wine shortage. Retrieved from: http://www.grapegrowersofontario.com/node/524

[10] Huneeus, A. (2005). Consolidation and the Future of Small, Premium Wineries. Wine Business Monthly. December.

[11] Johnson, R. \& Bruwer, J. (2007). Regional brand image and perceived wine quality: the consumer perspective. International Journal of Wine Business Research, 19(4), 276-297.

[12] Lamb, C. W., Joseph F. H., \& Carl, D. M. (2010). MKTG4: Student Edition. Mason, OH: South-Western Cengage Learning. Print.

[13] The Liquor Control Board of Ontario. (2013). Responsible Growth LCBO Annual Report 2011-12. Retrieved from: http://www.lcbo.com/content/lcbo/en/corporate-pages/about/ annual-report.html

[14] Lee, J. (2011). Export Specialization and Economic Growth around the World. Economic Systems, 35(1), 45-63.
[15] Ministry of Finance (2013). Ontario News. Retrieved from:http://news.ontario.ca/mof/en/2012/12/ontario-introduc ing-two-new-ways-to-buy-alcohol.html

[16] Mogk-Edwards, S. (2013). Shopping Patterns at the LCBO. Retrieved from:http://www.wgao.ca/uploads/2.\%20LCBO\% 20Trends.pdf

[17] Pigott, S. (2014). Best White Wine on Earth. Retrieved from: http://www.stuartpigott.de/?page_id=4787

[18] Radebaugh H., Sullivan D.P., \& Daniels J.D. (2011). International Business: Environments and Operations. (13th ed.). Upper Saddle River, New Jersey: Pearson Education.

[19] Radnor, H. (2002). Researching your own professional practice: doing interpretive research. Buckingham: Oxford University Press.

[20] Robinson, J. (2006). The Oxford Companion to Wine. Oxford: Oxford UP. Print.

[21] Tinney, M. (2006). Riesling: The New Darling White Wine. Retrieved from:http://www.winebusiness.com/wbm/?go=get ArticleSignIn\&dataId $=45643$

[22] Veseth, M. (2011). Wine Wars: The Curse of the Blue Nun, the Miracle of Two Buck Chuck, and the Revenge of the Terroirists. Lanham, MD: Rowman \& Littlefield, 2011. Print.

[23] Vintners Quality Alliance. (2014). Current and archived news articles relating to VQA Ontario. Retrieved from: http://www.vqaontario.ca/AboutVQA/News\#News

[24] Wine Country Ontario (2014). VQA Wine Facts \& Statistics. Retrieved from:http://winecountryontario.ca/media-centre/in dustry-statistics

[25] Ziraldo, D. J. P., \& Karl, K. (2007). Icewine: Extreme Winemaking. Toronto: Key Porter, 2007. Print. 